\title{
Development of Tourism Database Management System: Creating ER Model
}

Nur Shaffiqa Muhammad Soffian, Norsyazlin Mohd Rosli, Muhamad Azrul Azwan Azman and Ana Kashfi Muhamad

To Link this Article: http://dx.doi.org/10.6007/IJARBSS/v11-i2/9206

DOI:10.6007/IJARBSS/v11-i2/9206

Received: 13 December 2020, Revised: 19 January 2021, Accepted: 04 February 2021

Published Online: 26 February 2021

In-Text Citation: (Soffian et al., 2021)

To Cite this Article: Soffian, N. S. M., Rosli, N. M., Azman, M. A. A., \& Muhamad, A. K. (2021). Development of Tourism Database Management System: Creating ER Model. International Journal of Academic Research in Business and Social Sciences, 11(2), 1307-1314.

Copyright: (c) 2021 The Author(s)

Published by Human Resource Management Academic Research Society (www.hrmars.com) This article is published under the Creative Commons Attribution (CC BY 4.0) license. Anyone may reproduce, distribute, translate and create derivative works of this article (for both commercial and non-commercial purposes), subject to full attribution to the original publication and authors. The full terms of this license may be seen at: http://creativecommons.org/licences/by/4.0/legalcode

Vol. 11, No. 2, 2021, Pg. 1307 - 1314

Full Terms \& Conditions of access and use can be found at http://hrmars.com/index.php/pages/detail/publication-ethics 


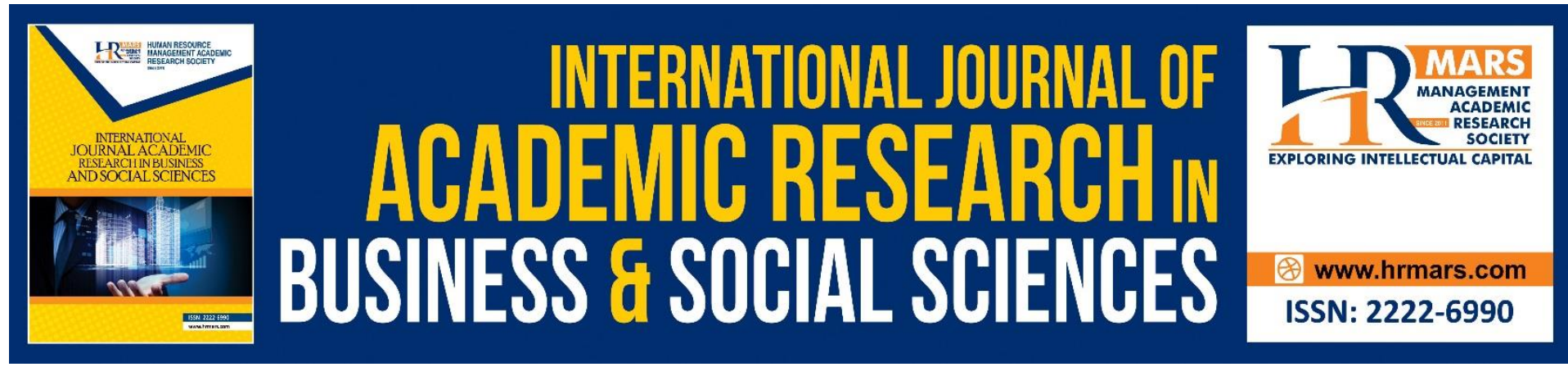

\title{
Development of Tourism Database Management System: Creating ER Model
}

Nur Shaffiqa Muhammad Soffian, Norsyazlin Mohd Rosli, Muhamad Azrul Azwan Azman and Ana Kashfi Muhamad Faculty of Architecture, Planning and Surveying, Universiti Teknologi MARA, Perak Branch, Seri Iskandar Campus, 32610 Seri Iskandar, Perak, Malaysia

\begin{abstract}
The tourism activity has slowed down since the pandemic Covid-19 and indirectly affected the whole world including Malaysia. Malaysia is slowly taking steps to revitalize the economy from tourism activities. At the same time, the local authorities are lacking information in gather tourism database and have problems with storing and managing spatial data in developing a Geographic Information System (GIS) database. Indirectly, most tourist attractions are lack of promotion by the local authorities in their respective areas. The main objective of this paper is to create ER Model for Tourism Database Management System for tourism destinations attractions in Malaysia. Therefore, the E-R technique is used as a graphical method of representing objects (or entities) of a database. The ER Model is hoped to create a user-friendly database that standardizes all tourism information for both parties in one database where it can facilitate the ministry and local authorities in making decisions, identifying problems and updating data related to the tourism sector.
\end{abstract}

Keywords: Database, Database Management System, ER Model, ER Diagram, Geographic Information System, Tourism

\section{Introduction}

Tourism is one of the sectors that provide income generation to the national economy where in the first quarter of 2019, Malaysia has recorded an overall tourism expenditure as RM21.4 billion compared to 2018 which is RM18.3 billion. (Tourism Malaysia, 2019). However, in 2020 , tourism expenses in Malaysia decreased by $41.5 \%$ which is RM12.5 billion compared to the first quarter of 2019 (Tourism Malaysia, 2020). This decrease is expected because of the transmission of coronavirus (Covid-19) which in March 2020 the state and national border gates were closed to prevent the spread of the virus. Therefore, the government began to take remedial measures through the Tourism and Culture Recovery Plan which will be drafted by the Ministry of Tourism, Arts and Culture (Husain, 2020).

Although the decline in tourism expenditure was due to the covid-19 outbreak, it was a new issue in the tourism sector. There are issues that are often discussed and highlighted such as the lack of promotion and marketing of the tourism sector in Malaysia. According to Aris \& Ahmad (2019), social media methods especially website users such as TripAdvisor application 
can help in promoting the tourism sector for particular state or area but the result from their study found that the level of effectiveness is still moderately high because it only helps to promote from the aspect of selling price not the selling experience.

Efforts to promote and market the tourism sector in Malaysia should be under the jurisdiction of the Ministry of Tourism, Arts and Culture. However, the ministry needs to realize that before promoting the tourism sector, they need to create a tourism database for each state in Malaysia and then the database can be used in promoting tourism in Malaysia through sales missions, filling ad slots in the media, participating in events and international tourism exhibitions through invited journalists, foreign travel writers and travel agency personnel (DBKL, 2020). In the Official Portal of the Ministry of Tourism, Arts and Culture, there are online services provided to the public or tourists to get information regarding tourism in Malaysia such as Tourism Products (e-Brochures), smartphone applications and open data. Through the smartphone application there are three (3) applications namely myMOTAC, Malaysia Trip Planner and e-Brochures. While for open data there is information such as Homestays in Malaysia, Statistics of Muslim Tourist Arrivals to Malaysia and others.

Local authorities can actually assist the ministry in promoting the tourism sector if they have a complete database according to the needs of the ministry where the database not only helps in promotion and marketing but able to assist in monitoring and updating tourism data in their area. The issue of tourism data at the local authority level can be seen when the public or tourists do not get complete information for tourist attractions in their administrative area. This information should be easy to access through various forms of application platforms or the internet, especially through the official website. For example, official website of Manjung Municipal Council does not provide any information regarding tourism in the district, while their main attractions are Pangkor Island and Jetty Port in Lumut. The next example is the Langkawi Municipal Council which provides tourism information on the official website but still incomplete in terms of providing important information as in e-Brochures created by the Ministry of Tourism, Arts and Culture. Here you can see that there is no uniform network of information and data from both parties. Therefore, researchers can conclude that the Ministry of Tourism, Arts and Culture has the data or information needed by tourists, but there is no database that stores that information that can be used by local authorities especially that have a lot of tourist attractions in their administrative areas.

This paper is designed to create a tourism database that can be used comprehensively by local authorities that have the same database network as the ministry of tourism. By using the Geographical Information System (GIS), the formation of this database can help ministries and local authorities standardize tourism information data as well as facilitate them to monitor and update the latest data regarding tourist attractions, tourism activities, price comparisons, operating hours and other important information.

The method used in this study is Entity Relationship Model or better known as ER Model. ER Model facilitates data storage where it can serve as the basis for databases that store problem domain data, and that use, modify, and restrict that data (Song \& Froehlich, 1994). 


\section{Literature Review \\ Database Management System}

Database design consists of four main phases including definition of specifications, analytical architecture, logical design and physical design (Amran et al., 2019). Database Management Systems (DBMS) on the other hand are specifically developed computer management systems that communicate with users, other systems and create database application as a data store and data access tool includes a strong database system (Amran et al., 2019). It also lets designers create practical and realistic concept models (Btoush \& Hammad, 2015). While Musa, Idowu \& Zemba (2014) stated in addition to the basic functionality of the database system, the ability of the GIS database to store, view, download and display spatial data (i.e. maps) is the main elements that set it apart from other databases.

\section{Entity Relationship Model}

Chronologically, the ER Model is an original idea from Chen (1976) cited by Bagui and Earp (2003), which only introduced the model to a combination of three (3) basic components namely entities, attributes, and relationships. According to Btoush \& Hammad (2015), ER models are used to manage and track databases of the system. Entity Relationship Diagram is a common diagram that helps to show the database structure in a visualized format (Almasree, 2015). An entity is represented in an ER model as a rectangle with the name of the entity. The names of the attributes are outlined in an oval that is attached to the rectangle they represent. Attributes can be removed to prevent cluttering the diagram at an early stage of creation (Song \& Froehlich, 1994).

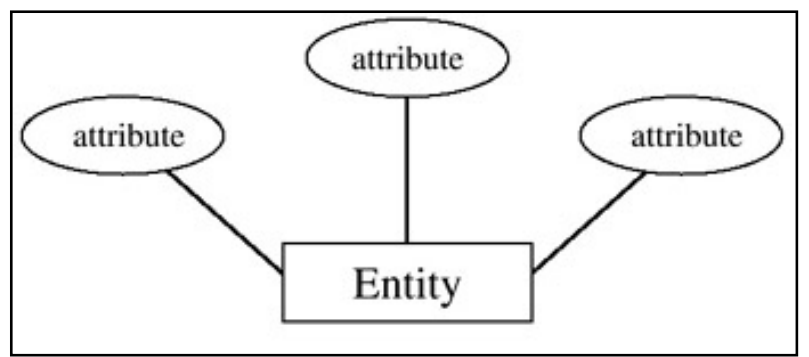

Figure 1: ER Model with three (3) attribute by Chen Source: Bagui and Earp (2003)

Table 1: Symbols for ER-Model

\begin{tabular}{|r|r|r|}
\hline \multicolumn{2}{|c|}{ Symbol } & \multicolumn{1}{c|}{ Description } \\
\hline & Rectangle & represents entity in the ER Model \\
\hline & Ellipse & represents attribute in the ER Model \\
\hline & Line & links attributes to entity sets \\
\hline
\end{tabular}

Source: Tutorialwing (2017)

The formation of ER model in forming a database system is seen to have an advantage to an organization. Referring to the researcher's reading, although the original idea of the formation of this ER Model was from Chen, but Chen did not clearly or set out a specific 
condition of what field or organization could adopt the ER Model. This means that the ER Model can be applied to all forms of organizations and fields that want to form a database system. This is because, there are many advantages to the ER Model if it is used in an organization. Everything on earth can be formed as a database if it has spatial data (physical form) and attribute data (information that can be analysed and manipulated). As stated by (Al-btoush, 2015), ER Model shows that the real world consists of a collection of entities, the relationships between them, and the attributes that describe them. In identifying data attributes, Amran et al., (2019) wrote that data can be collected based on existing systems or existing information in an organization such as documentation that will help in forming ER Model.

\section{Benefits of ER Model in Tourism}

(Mathew \& Mathew, 2016) stated that tourism industry seems to be evolve into another level in economic activity. It required the comprehensive management program be a solid organization that has met all industry norms. Compatible relations are often suggested. Working with such a program will make it possible for the consumer to get some details. Small cost of service and improved efficiency. As the database is being developed with a successful configuration, the machine will satisfy any need in the future. It is the most used complex queries and easy to be represent. The analytical, to integer translation proves that the database has been correctly constructed.

Onuiri et al. (2016) revealed that in the study of Intelligent Tourism Management System (ITMS) by applying ER Model for 50 tourist attractions including both natural and artificial in Nigeria it has led to an ability in implement a recommendation filtering device that will boost the science and flexibility of the method, while allowing visitors to make decisions. The built framework is user-friendly, responsive, and compliant with any web browser operating on every device and the guide has been perfectly crafted to improve the usability and performance and effectiveness of the website. In conclusion, this program can solve several of Nigeria's problems in terms of product management and tourism details. Tourists will get to learn all the tourist places in Nigeria and details relating to such places without actively collecting knowledge from locals or needing to drive long distances to see what the place must give. With the launch of the Internet, consumers have access to the ITMS application and are also encouraged to provide up-to-date and appropriate details on tourism in Nigeria. The program would go a fair way to encouraging visitors to make choices, as well as to providing the nation with a means of revenue. ITMS can make tourism across the world enjoyable and convenient because of quick access to the relevant details.

\section{Creating Entities, Attributes and Relationship}

To create a database that can standardize information and tourism data to ministries and local authorities, the ER Model used will formulate an entity, attribute and relationship referring to Chen's theory in 1976. Using the ER Model, both parties can serve as the basis for databases that store problem domain data, and that use, modify, and restrict that data (Song et al., 1995).As mentioned in the introduction, the ministry already has data and information with reference to eBrochures. Therefore, the formation of entities, attributes and relationships refers to eBrochures issued by Tourism Malaysia (2017) (refer to table 2): 
- Entities: region in Malaysia to facilitate the formation of the database that is Central, Southern, Northern, East Cost and East Malaysia

- Attributes: describe properties of entities including state, type of interest, place of interest and photo

- Relationship: match data with the same name and details

Table 2: Example attributes according to Central Region entity

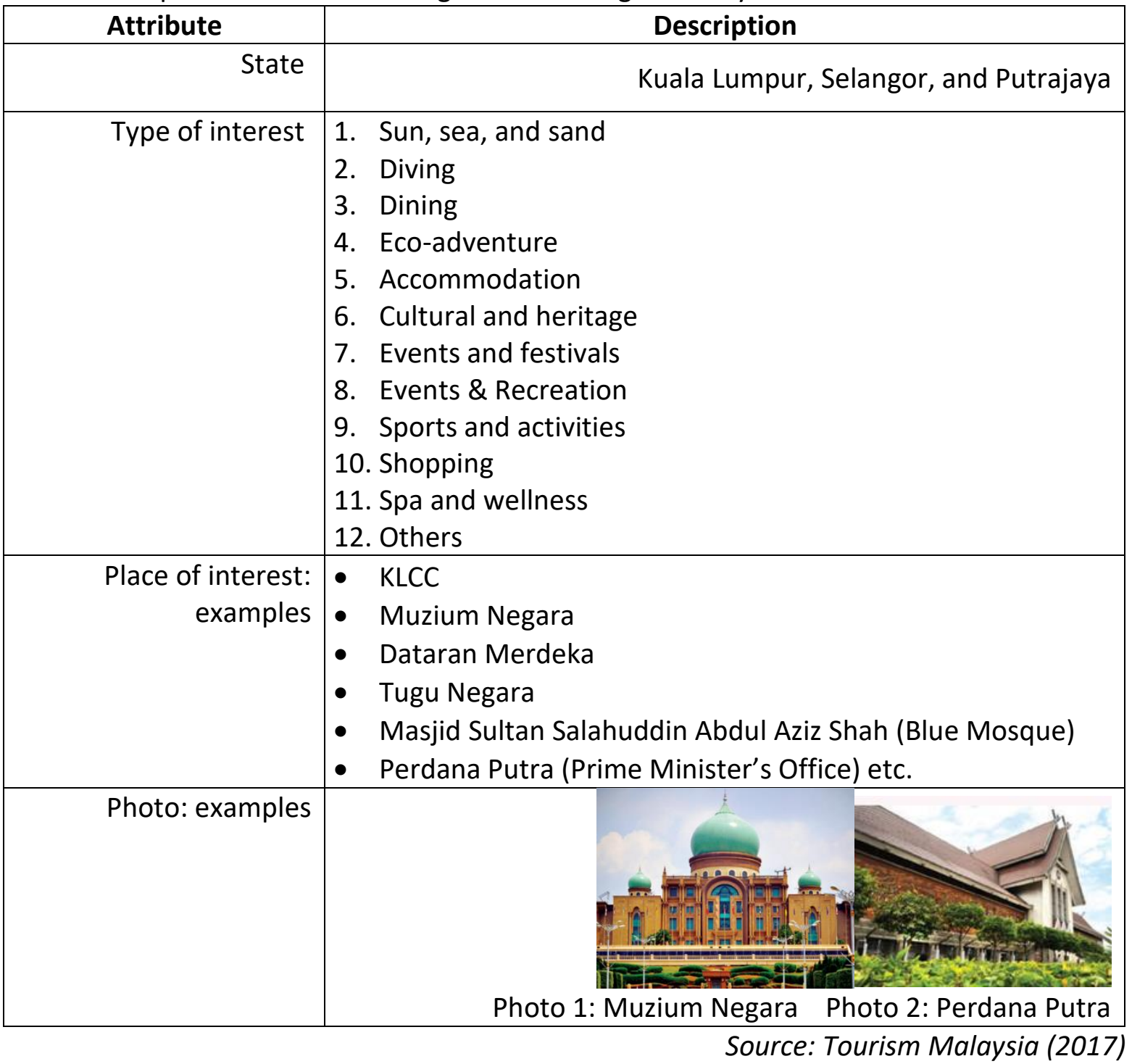

After entities, attributes and relationships are designed, according to Bagui and Earp (2003) by drawing a graphic diagram will help process data more easily and concisely (Bagui and Earp, 2003) (refer to figure 2). The diagram has several symbols that will represent entity, attribute, and relationship (refer to table 1 ):

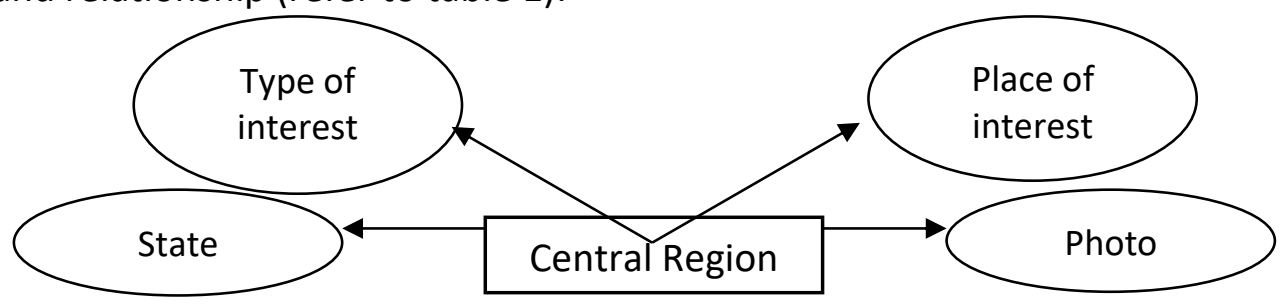

Figure 2: ER Model of Tourism Database Development in Malaysia with four (4) attributes 
This diagram will be developed by region in Malaysia. When all the regions are combined, it will form one (1) complete database for the tourism information database system. This database can be updated according to the current situation for example in this pandemic where we are going through the period of Restriction Movement Control Order (RMCO) and almost all tourism sectors have reopened but with the Standard Operating Procedure (SOP) set by the National Security Council. Therefore, by using the ER Model method for this tourism database information system, the ministry and local authorities can update the attribute by placing a new attribute such as "SOP action" or "SOP implementation".

\section{Conclusion}

Therefore, with the illustration and initial framework of this ER Model will actually help the ministries and local authorities in collecting data regarding the tourism sector that can facilitate and provide information to the public and tourists in accessing tourist attraction data. In addition, ER Model not only can create a database that standardizes all tourism information for both parties in one database but it can also facilitate the ministry and local authorities in making decisions, identifying problems and updating data related to the tourism sector. Therefore, this study suggests that the Tourism Database Management System using the ER Model is implemented into the appropriate software that is GIS so that it can be applied to the ministry and local authorities.

\section{References}

\section{Journal Article}

Al-btoush, A. A. (2015). Extracting Entity Relationship Diagram ( ERD ) from English Sentences. International Journal of Database Theory and Application, 8(2), 235-244. http://dx.doi.org/10.14257/ijdta.2015.8.2.22

Al-masree, H. K. (2015). Extracting Entity Relationship Diagram ( ERD ) From Relational Database Schema. 8(3), 15-26.

Amran, N., Mohamed, H., \& Bahry, F. D. S. (2019). Developing Human Resource Training Management (HRTM) Conceptual Model Using Entity Relationship Diagram (ERD). International Journal of Academic Research in Business and Social Sciences, 8(12), 1444-1459. https://doi.org/10.6007/ijarbss/v8-i12/5249

Aris, N. M., \& Ahmad, H. (2019). Mempromosikan Pelancongan Warisan di Melaka dalam Media Sosial Tripadvisor.pdf. Wacana Sarjana, 3(2), 1-13.

Btoush, E. S., \& Hammad, M. M. (2015). Generating ER Diagrams from Requirement Specifications Based On Natural Language Processing. 8(2), 61-70.

Musa, A. A., Idowu, T. O., \& Zemba, A. A. (2014). Gis Database Design and Implementation the Mautech Experience. International Journal of Computer Science and Engineering, 3(1), 47-56.

Song, I. Y., Evans, M., \& Park, E. K. (1995). A Comparative Analysis of Entity-Relationship Diagrams. Journal of Computer and Software Engineering, 3(4), 427-459.

Song, I. Y., \& Froehlich, K. (1994). A practical how-to guide Entity-Relationship modeling. IEEE Potentials, 13(5), 29-34. https://doi.org/10.1109/45.464652

Mathew, B., \& Mathew, B. (2016). Department of Computer Science Report on Tourism Management System Authors. (November). https://doi.org/10.13140/RG.2.2.15777.40807 
Onuiri, E. E., Omoroje, H. C., Ntima, C. G., \& Omotunde, A. A. (2016). Tourism Management System. American Scientific Research Journal for Engineering, Technology, and Sciences (ASRJETS), 18(May), 304-315.

\section{Book}

Bagui, S. \& Earp R. (2003). Database Design Using Entity-relationship Diagrams. CRC Press I LIc.

\section{Brochure}

Tourism Malaysia (2017). Malaysia Travel Guide [Brochure]. Tourism, Ministry of Tourism and Culture Malaysia.

\section{Website}

Husain, N. H. (2018). Sinar Harian. Retrieved from https://www.sinarharian.com.my/article/92252/BERITA/Nasional/Sektor-pelancongannegara-rugi-RM45-bilion-kata-menteri

Pelan Struktur Kuala Lumpur. (2020). Retrieved from https://www.dbkl.gov.my/pskl2020/malay/pelancongan/index.htm

Tourism Malaysia. (2019). Tourism Malaysia. Retrieved from https://www.tourism.gov.my/media/view/pendapatan-pelancongan-meningkatsebanyak-16-9-kepada-rm21-4-bilion-pada-suku-pertama-2019

Tourism Malaysia. (2020). Tourism Malaysia. Retrieved from https://www.tourism.gov.my/media/view/malaysia-sambut-4-23-juta-pelancongantarabangsa-bagi-suku-pertama-tahun-2020-turun-36-8-berbanding-2019

Tutorialwing. (2017). Retrieved from https://tutorialwing.com/er-diagram-in-dbms-components-symbol-and-notations/ 